\title{
Italian Literature for Children Translated into Albanian 1923 - 1989
}

\author{
M.Sc. Manjola Sulaj \\ "Eqrem Çabej" University of Gjirokaster, Faculty of Education and Social Sciences, Departament of Foreign Languages \\ Email: sulaj_manjola@yahoo.it \\ Lindita Rrapa \\ "Eqrem Çabej" University of Gjirokaster, Faculty of Education and Social Sciences \\ Email: ditinadi@gmail.com
}

\section{Doi:10.5901/mjss.2015.v6n3s2p388}

\begin{abstract}
Italian Literature for children, since the first decades of the last century until today has been and is still present in the Albanian cultural environment by prominent authors and their prominent works, which have influenced the esthetic and literary cultural education, not only of the young generations, but also of the adults. The object of our work has been the study of literary and cultural content of this literature translated into Albanian, which extends over a period of about a century. Our article aims to contribute to the further enrichment of studies devoted to creativity and translations of Italian literature for children to Albanian, to reflect chronological order publication of the works of Italian literature for children, gender, literary types most translated into Albanian, highlighting various values and problems of these books' translation between 1923-1989.

Keywords: translation of Italian literature for children to Albanian, starting period, period of dictatorship, chronology of publication of the translations, problems related to the translation.
\end{abstract}

\section{Introduction}

Over a period of more than 400 years there have been published in Albanian about 650 books translated from Italian, of which about 168 belong to Italian literature for children. The long list of these books consists in new publications, as well as in republished works or improved publications.

In his work "Tradita dhe probleme të letërsisë shqipe për fëmijë"1 ("Tradition and problems with Albanian literature for children"), Bedri Dedja (1930 - 2004) states that the history of translation for children begins with the translations with religious topic adapted for children, with noticeable didactic character back in 1592 by means of the book "Katekizmi"2 ("The Catechism") of the Spanish priest Ladesma (Jakob Ledesma, 1516 - 1575), translated from the Arbëresh Lekë Matrënga (1567 - 1619). In his view, the book conceived in the form of a dialogue for teaching religious beliefs, served as religious instructions for the children of the Arbëresh villages of Sicily and is considered the first book in Albanian written especially for children.

"Katekizmi" paved the way for the translation of other religious books, which had significant didactic character. Real translation of fiction books for children began in the late '800, when were translated into Albanian several works from world literature. In the period between the two world wars, the translation of authentic literature books for children increased significantly and took a prominent role, either filling in someway the gap created by the lack of original books for children, and as Astrit Bishqemi ${ }^{3}$ accepts, or in the motive or the model that provided literature for children to break away from textbooks and create autonomy. The large number of translations in this period shows the increased attention towards children. More than ever before, were being crumbled the language barriers through translation, bringing on children's hands, as well as on the adults' readers who were fans of children's literature and nostalgic about this age, a series of books that have left traces in the literature of countries' backgrounds. They brought them into light and would leave impressions that someone would long live even in Albania.

1 Bedri Dedja: "Tradita dhe probleme të letërsisë shqipe për fëmijë", Tiranë, Shtëpia Botuese "Naim Frashëri”, 1971, pp. 50 - 51.

2 Jakob Ledesma: "Dottrina Christiana", (composta dal reverendo padre dottor Ledesma della compagnia di Giesù), tradotta di lingua italiana nell'albanese per Luca Matranga, alunno del collegio Greco, in Roma, Presso Guglielmo Facciotto, 1592

${ }^{3}$ Astrit Bishqemi: Histori e Letërsisë Shqiptare për Fëmijë dhe të Rinj, botues Pëllumb Zekthi, Tiranë 2008, p. 101

${ }_{4}^{4}$ Bedri Dedja: "Tradita dhe probleme të letërsisë shqipe për fëmijë", quated work, p. 112. 
This article aims:

1. to contribute to the further enrichment of studies devoted to creativity and translations of Italian literature for children into Albanian,

2. to present the study of literary and cultural content of Italian literature translated into Albanian, which extends over a period of about a century,

3. to reflect chronological order publication of the works of Italian literature for children, gender, literary types most translated into Albanian,

4. to highlight various values and problems of the books' translation from Italian into Albanian language between 1923-1989.

\section{The Beginnings of the Translations of Italian Literature for Children into Albanian}

In reference to the research we have made in the Albanian National Library, the history of authentic literary translation from the Italian language starts in the period between the two world wars, precisely in 1923, when was published as a book dedicated to children the complete novel "Zemra" ("The heart") of the Italian writer Edmondo De Amicis (1846 1908). The Albanian reader was not introduced for the first time to his writings in 1923 with the publication of the novel "Zemra". Previously, in the first decade of the last century, a part of this writer's creativity were translated into Albanian from Asdreni (1872 - 1947) and were published in 1909 in the newspaper "Lirija". More precisely, in this newspaper, on August 1, 1909 (edition 54) we find an extract of "L'idiom gentile" ("L'idioma Pagan") of De Amicis, titled "Gjuha e stërgjyshërvet" ("The ancestral language") [with subtitle "Një Djali" ("To a fellow")], with the signature of Asdreni as translator, that follows even on next edition.

The book "L'idiom gentile" of De Amicis summarizes notes, considerations, judgments collected over the writer's life, whom the author turned and published in a literary form. The book is divided into three parts. The text that Asdreni has brought in Albanian is taken from the first part of the book with the original title "La lingua della patria" (The native language") and subtitle "A un giovineto" ("To a fellow"). There are around 5 pages in Italian, but Asdreni did not bring it fully in Albanian leaving untranslated some fragments of the original.

\section{Translations of Italian Literature for Children into Albanian between the Two World Wars}

In the '30s it is important to mention for its contribution in the dissemination of children's literature the magazine "Vatra $e$ Rinisë" (1933 - 1939) of Vasil Xhaçka (1895 - 1978), which at the time of King Zog, has the merit of one of the first Albanian magazines for children, as an important event for the time, which laid the foundation of the press for children. "Vatra e Rinisë", among the other merits, has the merit of the assistance given to the enhancement and enrichment of the reading funds for the Albanian children with the classic works of world literature for children as "Liza në botën e çudirave" (Alice in wonderland), fairytales of Andersen (Hans Christian Andersen, 1805 - 1875), etc.

On the pages of "Vatra e Rinisë" were not missing the translations from Italian language, which had been present from the first edition to the last one. In this magazine (edition no. 25 and no. 26 of 1933) is published the novel "Kikibio dhe Shapatorja me një këmbë" "The stories of Chichibio) of Giovanni Boccaccio (1313 - 1375) to whom the Albanian reader is introduced for the first time. It is about the fourth novel of the sixth day "Dekameroni" ("The Decameron") which is brought in section "Shkencëtarët e mëdhenj për të vegjlit" ("The great scientists for the children"). The translation into Albanian is preceded by a short article of the translator Koço Semini, titled "Novela më e bukur e Gjovanni Boccaccio" ("The most beautiful novelette of Giovanni Boccaccio"), where the author except hoisting the image of the Italian writer, makes a brief description of the book from which is extracted the novel. This novelette is brought as a reading to the children, because it suits the childish world. It has as central topic the wisdom of the characters from the lower stratum who succeed in considering themselves like their masters thanks to trickery and the ability of making quirks.

"Princi i çuditshëm i shkretinës" ("Odd prince of the desert"), another book of the Italian literature for children, is published in continuity in dozens of editions (from the first to the fifty-second edition) on the magazine "Vatra e Rinisë" in section "Rrëfime historike" ("Historical narratives") with the note Literaturë italiane (Italian literature). The writer of this novel, Arnaldo Cipolla (1877 - 1938), is considered at the time of the dictatorship as a negative example for the ideas brought to the field of literature for children and had been the cause of criticism towards the magazine which published "such books". Let us quote the essence of the book rejection during the dictatorship: "The magazine of V. Xhaçka, publishing "Princi i çuditshm i shkretinës", glanced only over the facade of the bourgeois label: charity, wisdom and courage of Prince of Jera, that it naively wanted to transmit to the children, and which is really nothing more than a silhouette. Basically, this novel justifies in front of the children's opinion the anti humanitarian policy of the imperialist 
countries in Africa, the policy of colonialism.» ${ }^{4}$

In chronological order the translations into Albanian from Italian literature for children, between the two world wars, are as follows:

- 1923 - E. De Amicis: "Zemra", novel, Botim i Ministris s'Arsimit, Shtypshkronja "Mbrothësija" - Kristo P. Luarasi, Tiranë 1923 (botimi i parë)

- $\quad 1932^{5}$ - E. De Amicis: "Zemra", novel, Botim i Ministris s'Arsimit, Shtypshkronja "Nikaj", Tiranë 1932 (botimi i dytë)

- 1933 - G. Boccaccio: "Kikibio dhe Shapatorja me një këmbë", novelette, botuar në revistën "Vatra e rinisë", Tiranë.

- 1933 - 1934 - A. Cipolla: "Princi i çuditshm i shkretinës", novelette, e cila botohet me vazhdim në dhjetëra numra të revistës "Vatra e rinisë", Tiranë.

- 1935 - C. Collodi: "Pinoku" (Pinocchio), novel, përkthyer nga Cuk Simoni, Botim i përkthyesit rr. Gurakuqit 40, Shkodër.

- 1938 - E. De Amicis: "Zemra”, novel, Botim i Ministris s’Arsimit, Shtëpia botuese "Kristo Luarasi", Tiranë 1938 (botimi i tretë)

The frequency during the years of publications translated from Italian, between the two world wars, is made with time distance, sometimes longer and sometimes shorter. From the above list it is clear that the number of books' titles published during this period is sparse (about 6 titles, including reprints). This could be explained with two main reasons: firstly difficult historic and economic circumstances of that period in Albania, restricted writing and reading in Albanian, due to lack of education of most of the population; secondly economic difficulty to provide the publication of a book was an obstacle to the translators' work. Yet, we can not exclude the fact of the deficiencies that may have the fund of National Library of Tirana concerning the publication of books of that period, which can make incomplete our list.

Although translations of Italian literature for children between the two world wars are numerous, they, in addition to those from other languages, played an important role in the education of generations of that period. Regardless the importance of translations of the Italian literature for children in terms of all foreign literature, it was not organized. The small number of books that were brought into Albanian with relatively large distance of time, were product of some intellectuals who were familiar to the success of Italian literature books for children around the world, like "Zemra" dhe "Pinoku", without which the Italian literature in Albania during the first half of the years' 900 would be almost nonexistent.

\section{Translations of Italian Literature for Children into Albanian during the Dictatorship}

Soon after the liberation in Albania were set the communist dictatorship. The Communist Party, the only political leader in our country, gave clear directives regarding the issues and themes of literature for adults and children, too, to which was given special attention. During this period Albanian literature for children was a committed and politicized literature and was called the same like adult's literature "socialist realism". So, extreme politicization, declarative expressions and excessive morals are also characteristics and weaknesses of children's literature of post liberation.

In addition to the original works of Albanian authors, which aimed children's education with "qualities and virtues" of communist morality, children's literature was enriched with translations of the works of global literature for children. However, during this period, the selection of books to be translated was not effectuated according to the artistic criteria, but according to the ideological preferring works of authors who came from countries that had the same political and ideological inclination with Albania. Statistics clearly show that the books of Russian authors dominate until the second half of '70, regardless the relations with this country had disrupted since 1961. In the range of translated works, young Albanian readers had the opportunity to be introduced to some of the classics of global literature, including the Italian one, like: Lev Tolstoy (1828 - 1910), Mark Twain (1835 -1910), Hans Christian Andersen (1805 -1875), Jules Verne (1828 - 1905), Daniel Defoe (1660 - 1731) etc., the Italians: Carlo Collodi (1826 - 1990), Edmondo De Amiçis, Gianni Rodari (1920 - 1980).

Regarding the Italian literature for children during the dictatorship, the lines dedicated to it in the press and critical studies are just a few. Despite the number of books of Italian authors brought into Albanian marks a significant increase compared to the period between the two world wars, their publication was in minority in relation to the other foreign

\footnotetext{
4 There in, pp. $112-123$.

${ }^{5}$ Cover page of this republication contains the note: "accepted as a school textbook from the Ministry of Education with decision No. 33, of 21 August 1923. Is reprinted with the authorization of the Ministry No. 4254, 19 November 1930", whereas on the second page is noted: publishing house "Nikaj", Tirana 1932. This indicates that the book was republished two years after the approval for reprint.
} 
languages.

The first book of Italian literature for children after liberation is the story "Rrugaçët e vegjël" ("Young tramps") (1956) of Gianni Rodari, translated by Gjegj Zheji (1926 - 2010), that comes after 21 years after "Pinoku" translated by Cuk Simoni, the last book published during the first period, in other words 24 years after the publication of the novel "Zemra" of De Amicis, which in 1938 is republished for the third time.

Gianni Rodari is the most translated author throughout the 50s, because there are published two other of his books "Aventurat e Çipolinos" ("The Adventures of Cipollino", 1958), translated by Gjergj Zheji and after one year "Aventurat e Tonino të Padukshmit" ("The adventures of Tonino the invisible", 1959), translated by Dhimitër Pasko (1907 - 1967), with illustrations of Hiqmet Agolli. Yet, during this period, is republished the novel "Zemra" (1957) of E. De Amicis, translation of Halit Selfo (1918 - 1964), and "Pinoku" (1959), translated by Cuk Simoni.

In the early 60s was translated into Albanian by Pashko Gjeçi (1918 - 2010) "Komedia Hyjnore" ("Devine Comedy", 1960 - 1962), the entire work of Dante Alighieri (1265 -1321). Fragments of this work were present in advance in high school anthologies. "Komedia Hyjnore" is the only work of the Italian literature which is analyzed in all literature textbooks until the $90 \mathrm{~s}$, from which were brought extracts ${ }^{6}$. During the dictatorship, this work is registered even in the bibliography of children's books, certainly in the category of books that are not written specifically for children, but over the time have been assimilated by the young readers.

Other books in the chronology of Italian books for children published in Albanian during the 60s, are: "Trediçinoja" ("Trediccino", 1961), Italian fairytale, translated by Donika Omari; followed by 2 other books belonging to the same year "Spartaku" ("Spartacus", 1964) of Raffaello Giovagnoli (1838 - 1915), novel translated by Bujar Doko, and "Zemra" (1964) of De Amicis, with notes prepared by Filip Ndocaj (1914 - 1982) for the pupils of the 6th grade; two years later is published "Aventurat e çipolinos" (1966, second edition) of Gianni Rodari, translated by Gjergj Zheji; in 1967 is published "Ç'erë kanë zanatet" ("The colours of trades", 1967) of Gianni Rodari, translated by Llazar Siliqi (1924 - 2001), with illustrations of M. Delin.

During these years is paid more attention to the critical writings dealing with problems of literature for children and youth. Although, their number is large there is no scientific article dedicated to the Italian literature for children, except a single article translated by De Amicis, titled "Dashuria për librin" ("Love for the book"), published in the magazine "Nëntori", 1961 (nr. 11, pp. 147 - 155), which will remain the only critical article dedicated to the Italian literature for children during the second phase.

During 1970 - 1971 were published 66 books of Albanian authors and only 14 books are translations from foreign literature, where still dominates Russian literature, followed by the French literature and rarely from the English and Chinese languages. Among books of foreign authors only one book is translation from Italian literature for children. We are referring to the book "Udhëtimi i Shigjetës së Kaltër" ("The blue arrow", 1970) of Gianni Rodari, translated from Russian by Adelina Abazi, with illustrations of M. Sanço.

Historical - gjeographical - scientific - technological published works during 45 years of the dictatorship are considered as socio - political, artistic - scientific and popularized scientific literature, involving those books that recognized children with a glorious past and bright future of the Albanian people and books that give scientific scholarly knowledge. From such a variety of books (Albanian and foreign) along the second phase, distinguish only two Italian literature books for children: "Mrekullitë e dritës dhe të tingullit" ("Miracles of light and sound") (1971) of Mina Ripanit, translated by Petro Zheji (1929), and the book of Marcello Argilli (1926) "Aventurat e gozhdës" ("The adventures of the nail') (1973), translated by Stavri Kristo.

In the course of $1972-1973$ there is an increasing number of publications from foreign literature. There have been published 120 such books, only 2 of which are from Italian literature: "Libri i gabimeve" (The book of errors", 1973) of Gianni Rodari, translated in Albanian by Eqrem Biba, and "Aventurat e gozhdës" (1973).

During 1974 - 1975 there were published 181 books from foreign literature, of which only one is from Italian literature: "Ditari i mësueses së re" ("The diary of the young teacher", 1974) Maria Giacobbe (1928), translated by Gj. Aleksi.

In the course of 1976 - 1977 is translated only one book of Italian literature, even this one reprinted, we are referring to the novel "Zemër" (1977) of Edmondo De Amicis.

During 1978 - 1979 were published a total of 142 books of Albanian authors (seventy-three in 1978 and sixty-nine in 1979); there were translated 11 books from the foreign authors (three in 1978 and eight in 1979); there dominate

${ }^{6}$ Lindita Kazazi: "La letteratura italiana nelle antologie delle scuole medie superiori albanesi dagli anni Quaranta agli anni Novanta", in "ALBANIE Traduzione, tradizione. La traduzione delle varianti linguistiche alle varianti culturali", Atti del Convegno Internazionale. Shkodër 5- 6 qeshor 2008. p. 233 
translations from French and English; there is only one Italian book: "Pinoku në Afrikë" ("Pinocchio in Africa", 1979), a novel of Eugenio Cherubini, translated from the original by Elvira Kola, illustrator Bardhyl Fico. Throughout these years are translated also books of Albanian literature into foreign languages. The first appears "Guna e zezë" ("The black cloak") of Gaqo Bushaka (1943) followed by 7 other books, all translated in Greek.

Between 1980 - 1981 are published 123 books of the Albanian authors. There are published 18 titles from foreign literature (twelve in 1980 and six in 1981), two of which belong to Italian authors: the story "Tompusi dhe mjeshtëritë" ("Tompus and the skills", 1980) of Mario Buzzicchini, translated from the original by Bashkim Elbasani, and the nouvelette "Fra Diavolo" ("Brother Devil", 1981) Massimo Grillandi (1921 - 1987).

During these years, continues the translation of Albanian literature books into foreign languages. There result 11 books, 10 translated in Greek and 1 in German.

In 1982, 10 books have been translated from the foreign literature for children, of whom no one is of Italian literature. There dominate books translated from French.

Throughout 1984 - 1988 are published three children's literature books from Italian: "Balena"( "The whale"), of lliane Roels, published in 1984, translated by Pranvera Xhelo; "Rrëfime për heronjtë e Trojës" ("Stories on the Troy heroes"), of Laura Orvieto, published in 1986, translated by Klio Evangjeli; "Ndodhi gazmore" ("Funny stories"), of Carlo Collodi, published in 1988, translated by Brikena Çabej;

Following we will submit a more detailed picture of the translation of the Italian literary works for children, during the period of post liberation to 1988, according to the chronology of works' publication.

- 1956 - G. Rodari : "Rrugaçët e vegjël" (story), Tirana

- 1957 - E. De Amicis: "Zemra" (novel), State Enterprise Publications, Tirana

- 1958 - G. Rodari: "Aventurat e Çipolinos" (novel), Tirana

- 1959 - G. Rodari: "Aventurat e Tonino të Padukshmit” (story), Naim Frashëri, Tirana

- 1959 - C. Collodi: "Pinoku" (novelette), Naim Frashëri, Tirana

- 1961 - "Trediçinoja" (Italian fairytale), Naim Frashëri, Tirana

- 1964 - E. De Amicis: "Zemra" (novel), School Publications Department, Tirana

- 1964 - R. Giovagnoli: "Spartaku" (novel), Naim Frashëri, Tirana

- 1966 - G. Rodari: "Aventurat e çipolinos", School Publications Department, Tirana

- 1967 - G. Rodari: "Ç'erë kanë zanatet”, School Publications Department, Tirana

- 1970 - G. Rodari: "Udhëtimi i Shigjetës së Kaltër", Naim Frashëri, Tirana

- 1971- M. Ripani: "Mrekullitë e dritës dhe të tingullit", Naim Frashëri, Tirana

- 1973 - G. Rodari: "Libri i gabimeve", Naim Frashëri, Tirana

- 1973- M. Argilli, G. Parca: "Aventurat e gozhdës", Naim Frashëri, Tirana

- 1974 - Maria Giacobbe: "Ditari i mësueses së re" (novelette), Naim Frashëri, Tirana

- 1977 - E. De Amicis: "Zemër" (second edition with retrenchments), Naim Frashëri, Tirana

- 1979 - E. Cherubini: "Pinoku në Afrikë" (novel), Naim Frashëri, Tirana

- 1980 - Mario Buzzicchini: "Tompusi dhe mjeshtëritë" (story), Naim Frashëri, Tirana

- 1981 - M. Grilandi: "Fra Diavolo" (stories and novelettes), Naim Frashëri, Tirana

- 1988 - C. Collodi: "Ndodhi gazmore", Naim Frashëri, Tirana

\section{Conclusions}

All the books published during 1923 - 1989 belong to prose. Despite their translation's quality, there is apparent the same problem, which is related to deficiencies in data publishing books:

1. Almost in their entirety, books have no data if they are translated from the original, from Italian, or from other languages, such as: "Udhëtimi i Shigjetës së Kaltër" (1970) of Gianni Rodari, translated from Russian by A. Abazi.

2. Also, most of the books with illustrations do not contain the name of the illustrator, underestimating him in such way. From a large number of books, we can list several: "Rrugaçët e vegjël" (1956), "Aventurat e Çipolinos" (1958), "Zemra" (1957), "Trediçinoja" (1961), "Mrekullitë e dritës dhe të tingullit" (1971), "Aventurat e gozhdës" (1973), "Libri i gabimeve" (1973) "Ditari i mësueses së re" (1974) etj. We recall that the illustrations of children's literature play an essential role, not only in the decoration of the pages that make the book's reading more entertaining, but they also contribute in creating a certanin sense, especially in preschool books. Childron books' illustration is an art in itself, and their author should not remain anonymous.

3. In some books is missing the translator's name, like in "Zemër" (1977), "Fra Diavolo" (1981) etc. 
4. Literary genders translated during the first phase are novel and novelettes, while the metrical is nonexistent.

\section{References}

Bishqemi, Astrit: "Histori e Letërsisë Shqiptare për Fëmijë dhe të Rinj", botues Pëllumb Zekthi, Tiranë, 2008.

Collodi, Carlo: "Pinoku", përkthyer nga Cuk Simoni, Botim i përkthyesit, rr. Gurakuqi 40, Shkodër, 1935.

Collodi, Carlo: "Pinoku", përshtatur në shqipen letrare nga Zef Simoni, "Naim Frashëri", Tiranë, 2000.

Collodi, Carlo: "Pinoku", shqipëruar nga Eri dhe Taulant Tafa, Botimet "Vëllezërit Tafa", Tiranë, 2006.

Collodi, Carlo: "Le Avventure di Pinocchio", Giunti Marzocco, Firenze, 1981.

Dedja, Bedri: "Tradita dhe probleme të letërsisë shqipe për fëmijë", Shtëpia Botuese "Naim Frashëri" , Tiranë, 1971.

De Amiçis, Edmondo: "Zemra", Botim i Ministris s'Arsimit, Shtypshkronja "Nikaj", Tiranë 1932

De Amiçis, Edmondo: "Zemra", Botim i Ministris s'Arsimit, Shtëpia botuese "Kristo Luarasi" 1938.

Gjokutaj, Tasim: "Letërsia shqipe për fëmijë ka nevojë më tepër për vlerësim" - LETERSIA SI E TILLE, T. 1996,

Kazazi, Lindita: "La letteratura italiana nelle antologie delle scuole medie superiori albanesi dagli anni Quaranta agli anni Novanta", in "ALBANIE Traduzione, tradizione. La traduzione delle varianti linguistiche alle varianti culturali", Atti del Convegno Internazionale. Shkodër $5-6$ qeshor 2008.

Kodra, Klara: "Pinoku, Piter Pani dhe Liza, tre shembuj të figurës së fëmijës në letërsinë botërore", shtëpia botuese "Elite", Tiranë, 1998.

Ledesma, Jakob: "Dottrina Christiana", (composta dal reverendo padre dottor Ledesma della compagnia di Giesù), tradotta di lingua italiana nell'albanese per Luca Matranga, alunno del collegio Greco, in Roma, Presso Guglielmo Facciotto, 1592

Missali, Gjon Stefa: "Oazi i artë i Gjuhadolit", Shtëpia Botuese "Gjergj Fishta", Lezhë, 2011.

Prifti, Naum: "Kolodi dhe vepra e tij", në "Ndodhi gazmore" të Karlo Kolodit, Shtëpia botuese "Naim Frashëri", Tiranë, 1987.

\section{Periodicals}

"Hylli i dritës", nr. 9, 1935.

"lllyria", nr. 21, 7 shtator 1935.

"Illyria", nr 23, 21 shtator 1935.

"Illyria", nr. 24, 28 shtator 1935.

"Leka", nr. 9, shtator 1935. 